\title{
Share-based remuneration: Per-director disclosure practices of selected listed South African companies
}

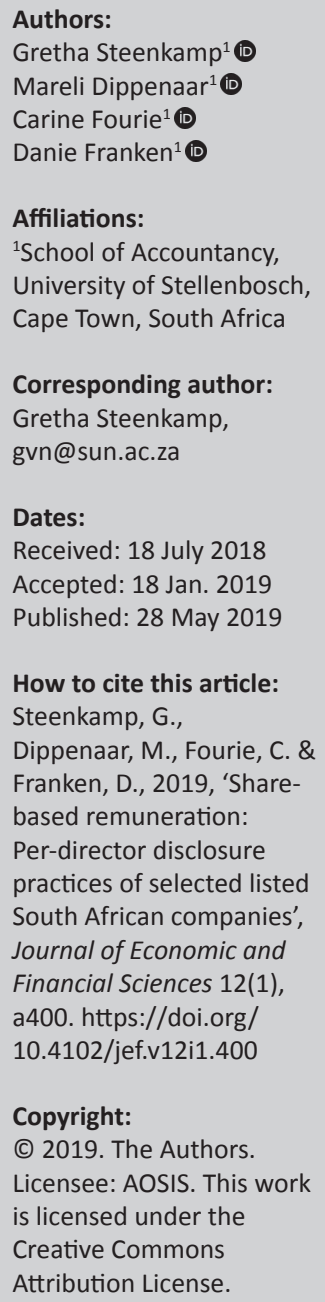

Orientation: The Johannesburg Stock Exchange (JSE), the Companies Act of 2008 (the Act) and the third King Report on Corporate Governance (King III) require disclosure on the share-based remuneration of directors of listed South African companies on a per-director basis.

Research purpose: The first objective was to determine the disclosure practices of JSE-listed companies relating to share-based remuneration on a per-director basis, to examine whether the disclosure practices comply with regulatory requirements and whether share-based remuneration was disclosed consistently. Comparisons were made between companies in the three largest industries on the JSE (financial, industrial and basic materials industries) as well as between small, medium and large companies. The second objective was to develop a bestpractice disclosure example that complies with the JSE listing requirements, the Act and the latest King Report (King IV).

Motivation for the study: Previous research has hinted that share-based remuneration is poorly disclosed in South African annual reports, but it has not specifically been studied.

Research approach, design and method: Data on disclosure practices were collected from annual reports. The collected data were analysed against the regulatory requirements to evaluate compliance and compared between companies to evaluate consistency.

Main findings: Some companies failed to comply with regulatory requirements (did not disclose the value of share-based remuneration and the number of instruments employed). Large companies were more likely than small companies to comply with regulatory requirements. Between-company inconsistency was noted when comparing the value of sharebased remuneration disclosed by companies in the sample.

Practical/managerial implications: Non-compliance with regulatory requirements regarding the disclosure of per-director share-based remuneration was noted in the sample, which could lead to stakeholders having insufficient information for decision-making purposes. Inconsistent disclosure practices, leading to incomparability between similar companies, could hamper effective investment decisions.

Contribution/value-add: A best-practice disclosure example was developed to assist companies seeking to comply with disclosure requirements and enhance comparability between JSE-listed companies in future.

Keywords: directors' remuneration; share-based payments; share-based remuneration; disclosure; Companies Act; King III; JSE listing requirements.

\section{Introduction}

\section{Orientation}

Directors' remuneration remains a contentious issue globally and in South Africa. Potentially excessive directors' remuneration is oft cited as an aggravating factor in the large income inequality experienced in the South African environment (Massie, Collier \& Crotty 2014). The relationship between some directors' pay and company performance is questioned, because directors receive large salaries, bonuses and share-based remuneration even when companies perform poorly (Urson 2016). Longterm share-based remuneration, such as share options and restricted shares, is increasingly used as part of the remuneration package for executive directors (PricewaterhouseCoopers 2012). In many cases, the proceeds from share-based remuneration exceed the proceeds from salary and other guaranteed benefits (Massie et al. 2014). Because of the magnitude of the rand values potentially involved, the governance of share-based remuneration is critical. Governance includes appropriate approval processes before share-based remuneration is implemented and transparent disclosure of the rand values involved per director, once implemented (Steenkamp \& Wesson 2018). In terms of 
governance through disclosure, both compliance with existing regulatory requirements and consistent between-company disclosure on share-based remuneration would be beneficial to shareholders, analysts and other users of the disclosures.

Several regulatory requirements that address the disclosure of directors' remuneration simultaneously apply to listed companies in South Africa. The Johannesburg Stock Exchange (JSE) listing requirements, the South African Companies Act No 71 of 2008 (henceforth 'the Act') and the King Report on Corporate Governance for South Africa (henceforth 'King Report') issued by the Institute of Directors in Southern Africa (IoDSA) all require disclosure of directors' share-based remuneration on a per-director basis. The JSE listing requirements and the Act list possible implications of noncompliance: private or public censures might be applied by the JSE; fines could become payable by the company; directors could be held responsible for any losses incurred by the company; directors might be removed from office; in a worst-case scenario, trading of the company's shares on the JSE might be suspended or terminated (JSE Limited 2016; Republic of South Africa 2008).

PricewaterhouseCoopers (2015) found that 'the overall level of long-term incentives...disclosure is not yet on par with global standards'. Companies were also not disclosing directors' remuneration properly in their annual reports, as required by the Act (Voller 2016). By 2018, the remuneration disclosure of certain JSE-listed companies was still vague (PricewaterhouseCoopers 2018). Very few local companies actually disclose the value of long-term incentive compensation (Steyn \& Cairney 2016). Because of the lack of explicit disclosure, such values need to be calculated by the users of the annual reports (using the information published in the companies' remuneration reports) (Steyn \& Cairney 2016). It seems that non-compliance with per-director disclosure requirements might be an issue, which would diminish the effectiveness of disclosures regarding executive remuneration as a governance measure.

Fischer (1989) and the International Accounting Standards Board (IASB) (2010) agree that consistent and comparable disclosure practices enable effective comparisons between companies and provide useful information for decisionmaking. Disclosure requirements relating to the value of sharebased remuneration (per director) were often interpreted and applied inconsistently by companies listed on the JSE, which leads to incomparability between similar companies (Dippenaar \& Steenkamp 2017). Some companies disclose the grant date fair value, while others disclose the fair value at reporting date or the gain on exercise (Dippenaar \& Steenkamp 2017). This inconsistency decreases the effectiveness of the governance role played by disclosures.

\section{Research purpose and objectives}

The primary objective of this study was to determine the disclosure practices of JSE companies, relating to long-term share-based remuneration on a per-director basis. This was done to determine whether the disclosure practices comply with the JSE listing requirements, the Act and the third King Report (henceforth 'King III') (which was effective at the time) and whether share-based remuneration was being disclosed consistently. Comparisons were also drawn between companies in different industries and of different sizes, to determine if there were significant differences in their disclosure practices. The findings will allow a conclusion on whether per-director share-based remuneration disclosures in the South African environment are currently functioning as an effective governance tool.

The secondary objective was to develop a best-practice perdirector disclosure example for long-term share-based remuneration paid to directors that complies with the JSE listing requirements, the Act and the fourth King Report (henceforth 'King IV'). King IV is effective for financial years starting on or after 01 April 2017.

The findings of this study are relevant to regulators to inform them about non-compliance with certain aspects of regulatory requirements and could be useful when drafting new regulations or clarifying existing requirements. Preparers of company annual reports will benefit from the findings as they lead to an improved understanding of the per-director disclosure requirements contained in multiple regulatory sources. The disclosure example developed will be useful for preparers seeking to comply comprehensively and consistently with the per-director disclosure requirements. The findings will enable shareholder activism as shareholders and other users of annual reports will be aware of the disclosures prescribed by all regulatory sources. Shareholders can then demand that these disclosures be provided comprehensively and consistently in companies' annual reports. Improved disclosure would provide improved information for decision-making to shareholders. The practical implications of the findings of this study will be highlighted for all stakeholders.

\section{Literature review}

\section{Defining share-based directors' remuneration}

A share-based payment (SBP) can be defined as any payment made in exchange for goods or services, if the value of such payment depends on the company's share price (IASB 2004). Such payments can be made to employees (including directors) or non-employees. This study focussed on payments made to directors. In terms of International Financial Reporting Standard (IFRS) 2, SBPs can be classified as either cash-settled (eventually settled in cash) or equitysettled (eventually settled in shares or share options) (IASB 2004).

Share-based payments usually have a grant date, when the award is made to the directors, followed by a vesting period, during which the director needs to remain in service of the company and other vesting conditions potentially need to be met (Massie et al. 2014). Following the successful completion 
of the vesting period, the director becomes entitled to the payment (this is called the 'vesting date'). Some SBPs are automatically payable on the vesting date, and some can only be exercised by the director during a following exercise period (Steenkamp \&Wesson 2018). Upon considering the lifespan of SBPs, it follows that SBPs can be measured at different dates (e.g. at grant date, vesting date or exercise date), leading to different values disclosed in annual reports. Other measurements include the IFRS 2 expense, calculated in terms of accounting rules, which could be based on fair value at reporting date for cash-settled SBPs or the grant date fair value for equity-settled SBPs (IASB 2004).

Share-based payment schemes can be divided between appreciation schemes and full quantum schemes (Mavrodinov 2012). Appreciation schemes include share options (usually equity-settled) and share-appreciation rights (cash-settled) and only reward for the increase in the share price from grant date to exercise date, without sharing in the risk that the share price will decrease (Steenkamp \&Wesson 2018). Full quantum schemes remunerate the director with the actual value of a share and expose the directors to both increases and decreases in the share price (Steenkamp \& Wesson 2018). Typical full quantum schemes are restricted and conditional shares. Globally and in South Africa, share options were widely employed until 2005, when IFRS 2 was implemented and companies had to start expensing share options (Pretorius \& De Villiers 2013). From 2006, share options were slowly replaced by share-appreciation rights and, more recently, by full quantum schemes (Steenkamp \& Wesson 2018). Full quantum schemes are viewed as more appropriate long-term incentives, as they provide improved alignment of directorshareholder interest (Steenkamp \& Wesson 2018).

\section{The development and governance of share- based directors' remuneration}

Share-based remuneration evolved from the agency theory. The central agency problem that exists in modern companies is the conflict of interest between the shareholder-owners and the manager-agents. Directors are contracted by the shareholders to monitor management's actions (should act as corporate monitors) and should be incentivised to act in the interest of the shareholders and not in their own interest (Jensen \& Meckling 1976). One way to incentivise directors is to link their remuneration to the share price of the company.

The managerial power (or rent extraction) theory was developed in an attempt to explain the increased usage of share-based remuneration for directors. This theory proposes that share-based remuneration allows directors the opportunity to 'extract rents' from the company they work for (i.e. to earn unwarranted remuneration that the shareholders are unaware of) (Bebchuk, Fried \& Walker 2002). Given the intricate nature of share-based schemes, as well as the complexities surrounding the recognition and disclosure thereof, there are many opportunities for such abuse. These opportunities include managing the earnings per share and share price, through accounting management and share repurchases (Steenkamp \& Wesson 2018).
Proponents of the agency theory view share-based remuneration to directors as an effective form of corporate governance (Ntim et al. 2015) in that it aligns the interest of shareholders and directors. However, most stakeholders agree that share-based remuneration exposes the company to risk that needs to be governed through adequate approval processes (utilising independent directors and shareholders) and per-director disclosure of share-based remuneration in the annual reports (Steenkamp \& Wesson 2018).

\section{Disclosure requirements relating to share-based directors' remuneration in the South African context}

In addition to complying with IFRS, publicly listed South African companies have to meet the disclosure requirements set out in the JSE listing requirements, the Act and the King Report. This study focusses on the disclosure requirements contained in the aforementioned regulatory requirements as they relate to the per-director disclosure of the number of share-based remuneration instruments and the value thereof.

\section{Johannesburg Stock Exchange listing requirements}

The JSE listing requirements require remuneration to be disclosed per director in the annual reports of listed companies. Regarding share-based remuneration, the JSE listing requirements focus on the number, rather than the value, of instruments and require the following to be disclosed per director:

- the number of share options or any similar right (instruments) in the opening balance (including the respective exercise prices, if applicable)

- the number of instruments awarded during the year (with their respective exercise prices, if applicable)

- the number of instruments exercised during the year (including the exercise prices, if applicable)

- the number of instruments in the closing balance (with their respective exercise prices, if applicable).

It is recommended that this information be presented in a tabular format as far as possible (JSE Limited 2017). Notably, King III and the Act contain no requirements to disclose the number of share-based instruments held but rather focus on the value of such instruments.

\section{The Act}

The Act requires remuneration to be disclosed per director in the annual reports of companies registered in South Africa that are legally required to be audited (which includes listed companies). The 'value of any option or right given...to a director' should be disclosed as part of remuneration, in terms of Section 30(6)(e) of the Act. The term 'value' is not defined in the Act, and according to Dippenaar (2018) possible interpretations include grant date fair value, fair value at reporting date, fair value on vesting date, IFRS 2 expense, gain on exercise as well as intrinsic value at reporting date. Dippenaar (2018) proposes that the most likely meaning is the grant date fair value. The uncertainty created by the undefined term 'value' (not specifying how and when this value should be measured) 
could lead to inconsistent application, and therefore incomparability, between similar companies.

The previously effective Act was the Companies Act No 61 of 1973 (henceforth '1973 Act'). Section 297 of the 1973 Act required disclosure of the gain on exercise of share options, but not per director (Republic of South Africa 1973). Notably, the requirement only related to share options, while the requirement contained in the 2008 Act has been broadened to refer to 'any option or right'. The calculation of the gain required by the 1973 Act was specified as the difference between the exercise price paid by the director and the market price of the shares on the date of exercise. In addition, the 1973 Act prescribed that the details of the gain should be disclosed in a tabular format, while the 2008 Act contains no such format prescription (Dippenaar 2018). Dippenaar and Steenkamp (2017) found that some companies still disclose the gain on exercise of share options, as was required by the 1973 Act.

\section{King report}

Companies listed on the JSE are required to comply with the King Report (JSE Limited 2017). King IV is only effective for financial years starting on or after 01 April 2017. The previous version of the report (King III) was still effective during the period covered by this study. King III required that remuneration should be disclosed on a per-director basis, as required by the Act (IoDSA 2009). Because the Act does not define which 'value' should be disclosed regarding sharebased remuneration, the remuneration practice note for King III can be used to provide guidance in this regard. The remuneration practice note for King III prescribes that the following should be disclosed in the remuneration report: the grant date fair value of the rights, complemented by the fair value at reporting date and gain on exercise of the awards (IoDSA 2013). The remuneration report template, provided for information purposes only, recommends disclosure in tabular format.

The requirements for the disclosure of share-based remuneration per director, as contained in the King Report, evolved over the years as the need for transparency for shareholders increased (PricewaterhouseCoopers 2018). Shareholders require sufficient information regarding relevant transactions to make informed decisions when voting and investing. The first King Report was effective when the most popular share-based remuneration was share options, and it required that the option exercise price, market price of shares at reporting date and market price of shares on exercise date be disclosed on a per-director basis (IoDSA 1994). The second King Report did not specifically require any value of share options to be disclosed but rather recommended 'full disclosure' with regard to share option schemes (IoDSA 2002).

King IV clarifies that share-based remuneration should be disclosed on a per-director basis in separate tables for each of the following (IoDSA 2016):
- The fair value of each remuneration element, including share-based remuneration, and a single, total figure of remuneration (single-figure table).

- For unvested awards, disclosure is required on the number of the awards, the dates that the awards vest and expire, the grant date fair value and the fair value at reporting date.

- For awards that were settled during the reporting period, the cash value-akin to gain on exercise-should be disclosed.

King IV has incorporated the values recommended in the remuneration practice note for King III into the King Report itself. When considering the single-figure table detailing each remuneration element, it should be noted that 'remuneration' is a defined term in the Act, and therefore the value of sharebased remuneration referred to would be the 'value of any option or right given'. The measurement of the 'value' of share-based remuneration to be included in the single-figure table is still not defined by the Act, and companies struggle to calculate it accurately (PricewaterhouseCoopers 2018). In line with Dippenaar (2018), the value of share-based remuneration to be disclosed in the single-figure table can be assumed to be the grant date fair value.

\section{Previous studies dealing with the disclosure of directors' share-based remuneration}

The next section provides details on selected global and South African studies on the disclosure of directors' sharebased remuneration. Only previous studies that have focussed on actual disclosure practices or included sharebased remuneration in measuring remuneration are mentioned. Extensive research has been conducted on the link between company performance and executive remuneration. However, many performance-pay studies contain no information on actual disclosure practices employed by companies and exclude share-based remuneration in measuring remuneration (Steyn 2015).

\section{Global studies}

A number of global studies have been conducted on the disclosure of share-based remuneration, which indicates that poor disclosure of share-based incentives is not merely a South African problem. Murphy (2012) conducted a longitudinal study on directors' remuneration in the USA and concluded that the grant date fair value and gain on exercise of share-based remuneration were substantially different. Disclosing only the grant date fair value, and not the gain on exercise, could severely detract from the information quality provided by annual report disclosure. If some companies only disclose the grant date fair value, while others only disclose the gain on exercise, this could hamper comparability between similar companies. Both these issues would decrease the transparency of the share-based remuneration disclosures.

Chief executive officer (CEO) remuneration disclosure in Australia was investigated by Clarkson, Van Bueren and Walker (2006) from 1998 to 2004. Significant improvements in 
disclosure were identified in 1998-1999 and again in 20032004, when certain disclosure requirements became mandatory. It was suggested that the most effective way of improving CEO remuneration disclosure is through formal regulatory channels. The disclosure requirements should be detailed, unambiguous and prescriptive, disallowing room for inconsistent application. Larger companies were more likely to have compliant disclosure. Coulton, James and Taylor (2001) also studied the 1998-1999 introduction of mandatory disclosures in Australia and found that larger companies had more transparent disclosure (provided more detailed disclosures).

While Clarkson et al. (2006) and Coulton et al. (2001) considered the effect of mandatory requirements regarding directors' remuneration, Conyon, Mallin and Sadler (2002) studied voluntary recommended disclosure regarding share options in the UK. They found that larger companies were less likely to disclose the recommended information, because of potential proprietary costs. In a more recent study in Malaysia, Jaafar, Nawawi and Salin (2014) similarly found that smaller companies were more likely to comply with the voluntary directors' remuneration disclosures recommended by the Malaysian Code of Corporate Governance.

Malak (2015) specifically considered per-director disclosures of executives in Malaysia between 2000 and 2008. Some voluntary per-director disclosures were recommended by the Malaysian Code of Corporate Governance (the actual figure of per-director executive remuneration), while the stock exchange's listing requirements prescribed mandatory disclosure of the band (e.g. between RM0 and RM50 000, between RM50 001 and RM100 000) into which per-director executive remuneration falls. Malak (2015) recommended that the inconsistencies between requirements of the Malaysian Code of Corporate Governance and the stock exchange's listing requirements be removed to improve disclosure. Malak (2015) found that larger companies were more likely to comply with the voluntary requirement to disclose per-director figures for executive remuneration. This was linked to a desire to be seen as legitimate in the environment in which the company operates.

\section{South African studies}

Table 1 provides a summary of previous studies conducted in South Africa that mentioned the actual annual report disclosure practices of South African companies regarding per-director share-based remuneration. These studies only referred to certain aspects of share-based disclosures as a side note, but the actual per-director disclosure practices regarding share-based remuneration-and whether it complies with regulatory requirements and was consistently applied-has not been specifically researched in South Africa. The King Report stipulates that non-executive directors should not receive share-based remuneration. As such, these studies all relate to executive directors.

Many previous South African studies on directors' remuneration (especially those dealing with the payperformance link) excluded share-based remuneration because of the complexities surrounding the measurement thereof (Steyn 2015). PricewaterhouseCoopers (2018) annually investigates key trends in executive remuneration in South Africa but only reports on guaranteed pay and short-term incentives. Thomson et al. (2018) evaluated the quality of annual report disclosures relating to short-term variable executive remuneration (they did not consider longterm share-based incentives). They found that disclosure quality varied across the companies sampled, which speaks of inconsistent disclosure practices.

Crafford (2015) included measures for share-based remuneration but only used amounts obtained from financial databases to capture executive remuneration and did not consider annual report disclosure. The gain on shares and share options were not recorded accurately in some financial databases because of inconsistent disclosure practices in annual reports (Steenkamp \& Wesson 2018).

Madlela and Cassim (2017) explored the adequacy of the disclosure requirements of the Act relating to directors' remuneration, as opposed to companies' actual disclosure practices. They also compared the South African requirements to those of the UK Companies Act. They criticised the

TABLE 1: South African studies on share-based remuneration.

\begin{tabular}{|c|c|c|c|}
\hline Authors & Aim & Sample (and time frame) & Main findings and mention of disclosure \\
\hline $\begin{array}{l}\text { Steenkamp and } \\
\text { Wesson (2018) }\end{array}$ & $\begin{array}{l}\text { Evaluated the trends in executive } \\
\text { share-based incentives in South } \\
\text { Africa and the reliability of the } \\
\text { available data sources thereof. }\end{array}$ & 33 JSE-listed companies (2002-2015) & $\begin{array}{l}\text { Differences in companies' disclosure practices, relating to the gain on } \\
\text { share-based incentives, were observed. This makes comparisons } \\
\text { problematic and increases the risk that executives could be utilising } \\
\text { share-based incentives to extract rents from companies. }\end{array}$ \\
\hline Urson (2016) & $\begin{array}{l}\text { Investigated the pay ratios of CEOS } \\
\text { in South Africa, by investigating the } \\
\text { prevalence of the tournament and } \\
\text { behavioural theories. }\end{array}$ & 77 JSE-listed companies (2006-2014) & $\begin{array}{l}\text { There is generally no relationship between the CEO pay ratio and } \\
\text { company performance. Inconsistent disclosure by companies, inter alia, } \\
\text { creates difficulties when accounting for and measuring share-based } \\
\text { incentives. The author criticises the South African disclosure } \\
\text { requirements relating to directors' remuneration, recommending that } \\
\text { companies be required to make more comprehensive per-director } \\
\text { disclosures of their compensation schemes. }\end{array}$ \\
\hline Steyn (2015) & $\begin{array}{l}\text { Investigated the relationship } \\
\text { between executive remuneration } \\
\text { and company performance. }\end{array}$ & Top 100 JSE-listed companies (2011-2013) & $\begin{array}{l}\text { Inconsistent disclosure by companies, inter alia, creates difficulties } \\
\text { when accounting for and measuring share-based incentives. }\end{array}$ \\
\hline Massie et al. (2014) & $\begin{array}{l}\text { Described the remuneration } \\
\text { packages of CEOs. }\end{array}$ & 50 JSE-listed companies (2012) & $\begin{array}{l}\text { Share-based remuneration provides directors with the incentive to } \\
\text { increase company share price in the short term (e.g. through share } \\
\text { repurchases) with a long-term negative effect on the company. This } \\
\text { should be monitored, but monitoring is only possible if proper } \\
\text { disclosure is provided in annual reports. There is inconsistent disclosure } \\
\text { between companies. }\end{array}$ \\
\hline
\end{tabular}


South African disclosure requirements and recommended that the requirements of the Act be improved and the reporting standardised to achieve enhanced transparency.

Ntim et al. (2012) evaluated the voluntary compliance of companies with King II's requirements (one of the requirements related to the disclosure of share options). They found that larger companies and those in the consumer services sector were more likely to comply with King II's requirements voluntarily. A similar study focussing on the Alternative Exchange also found that larger companies were more likely to comply with the requirements of King II and King III (Scholtz \& Smit 2015).

\section{Research methodology}

A positivistic research approach was followed. To address the first research objective (determining the compliance and consistency of per-director share-based remuneration disclosures), a quantitative research approach was applied, using data obtained from the annual reports for a sample of companies. To address the second research objective (development of a best-practice example of the per-director disclosure that complies with regulatory requirements), the regulatory requirements were combined with the examples of annual report disclosure encountered during the study that were most complete and user-friendly.

\section{Sample selection}

A sample of companies that have a primary listing on the main board of the JSE and that utilise SBPs as remuneration for their directors were selected. A final sample of 62 companies was selected, representing the three largest industries (financial, industrial and basic materials) and three different size groups (small, medium and large companies). The three largest industries on the JSE were selected because of their impact on the economy. Labour disputes in especially the basic materials sector also make this an interesting setting for studying disclosure practices regarding directors' remuneration.

The 62 companies were selected using the following process: A list of all companies listed on the JSE on 30 June 2017 (with the JSE as the primary listing) was obtained. The three largest industries, in terms of the number of companies in the industry, were identified as the financial, industrial and basic materials industries. These three industries represent $72 \%$ of the total number of companies listed on the JSE as at 30 June 2017. The list was sorted in descending order, based on the market capitalisation per company. Thereafter the list was divided into three equal segments, each containing 110 companies and labelled 'large', 'medium' and 'small'. Next, a sample of the seven largest companies was selected per segment (small, medium and large) and from each industry (financial, industrial and basic materials), resulting in a total of 63 companies being selected (21 large companies, 21 medium companies and 21 small companies, with seven from each industry per size category). If a selected company did not employ SBPs as directors' remuneration, it was replaced by the next largest company on the list, from that same industry and size segment. However, there were only six companies in the financial industry's small segment that incorporated SBPs in their directors' remuneration. This resulted in a final sample of 62 companies. For each of the 62 companies, their latest annual report, at the time the research was conducted, was selected. The reporting dates varied between 31 March 2016 and 30 June 2017, which were all before the effective date of King IV.

\section{Data collection process}

Each company's selected annual report was inspected to answer three types of questions pertaining to per-director share-based remuneration data. The questions were as follows:

- Location-based question (to assess consistency), namely: Where in the annual report was the disclosure presented?

- Value-based questions (to assess compliance with valuedisclosures required by the Act and King III, as well as consistency), namely:

- Which value (if any) was disclosed anywhere in the annual report?

- Was there a value disclosed with other short-term remuneration?

- If disclosed with short-term remuneration, which value was disclosed?

- Number-based question (to assess compliance with the JSE listing requirements), namely:

Which information was disclosed with regard to the number of instruments held in the opening balance, awarded, exercised and held in the closing balance?

\section{Data analysis}

Descriptive analyses were conducted to investigate trends. Chi-square tests were performed to compare the findings pertaining to companies in different industries (financial, industrial and basic materials industries) and those of different sizes (small, medium and large) to test whether statistically significant differences in disclosure practices existed between companies in the different industries and size-groups. A $5 \%$ level of significance was used to determine significant differences.

\section{Best-practice disclosure example}

A best-practice example of per-director share-based remuneration disclosure was developed. The aim was to develop an example that was both user-friendly and complied with the JSE listing requirements, the Act and King IV. This was done by combining the findings of Research Objective1, examples of user-friendly disclosure noted in the annual reports studied, as well as the requirements of the regulatory requirements detailed in the literature review. It was deemed important that the number of instruments and value thereof be clearly indicated and easily associable with each other. 


\section{Reliability and validity considerations}

A study is considered to have produced reliable results if it can be repeated and similar results obtained by the second researcher. The research process followed is described in depth in the preceding sections-as such, the study can be replicated. During the data collection process, a rigorous approach was followed, whereby one researcher collected the data and another checked it. Where the disclosure practices of a specific company was uncommon or difficult to categorise, the practices were discussed between researchers and classified based on the communal decision. The data were collected in a custom-designed spreadsheet, which could only be accessed by the researchers.

A study is viewed as valid if the research methodology allows the researchers to answer the question(s) that they set out to answer (internal validity). In this case: did the research measure the per-director disclosure practices of selected JSE-listed companies and assess them for compliance and consistency (Research Objective 1) and develop a best-practice disclosure example that complies with all regulatory requirements (Research Objective 2)? The actual disclosure practices as found in the annual report were scrutinised and compared to the relevant regulatory requirements to ascertain compliance, and they were then compared across industries and between companies of different sizes to ascertain consistency. As such, the study produced internally valid results.

A second aspect of validity is external validity. Research is seen as externally valid if the research findings can be generalised to other samples of JSE-listed companies. In this case, the findings of Research Objective 1 (disclosure practices) cannot be generalised beyond the sample, leading to a scope limitation, but the reliability of the results are strengthened by the fact that companies of various sizes and from various industries were sampled. However, the bestpractice disclosure example (findings of Research Objective 2) could be utilised by all JSE-listed companies.

\section{Results regarding Research Objective 1 (disclosure practices) Compliance and consistency of disclosure practices in the sample}

Several data items were collected (as explained in the section labelled 'Data collection process') regarding the per-director share-based remuneration for the 62 companies included in the sample. In Table 2, descriptive statistics are provided regarding the location, value and numbers-based disclosure per director. As companies often disclose share-based remuneration in more than one location or disclose more than one value in their annual reports, the percentages displayed in the table do not always add to $100 \%$.

\section{Location-based: Placement of the disclosure in the annual report}

The annual reports of the selected companies were inspected to determine the placement of the per-director share-based remuneration disclosure. This was done to assess whether
TABLE 2: Findings on disclosure of share-based remuneration.

\begin{tabular}{|c|c|}
\hline Variables & Percentage of companies (\%) \\
\hline \multicolumn{2}{|l|}{ Location-based } \\
\hline Directors' report (general section) & 10 \\
\hline $\begin{array}{l}\text { Separate section of the directors' report, namely } \\
\text { 'Remuneration report' }\end{array}$ & 29 \\
\hline Directors' remuneration note to AFS & 46 \\
\hline Related parties' note to AFS & 19 \\
\hline IFRS 2 note to AFS & 13 \\
\hline \multicolumn{2}{|l|}{ Value-based (disclosed anywhere in AFS) } \\
\hline Exercise date fair value (same as gain on exercise) & 65 \\
\hline $\begin{array}{l}\text { Fair value of instruments awarded during year } \\
\text { (grant date fair value) }\end{array}$ & 37 \\
\hline IFRS 2 expense & 16 \\
\hline Fair value at reporting date & 19 \\
\hline None & 6 \\
\hline \multicolumn{2}{|l|}{ Value-based (placement of values) } \\
\hline $\begin{array}{l}\text { Provided in table with short-term remuneration, } \\
\text { but no further information in the remainder of AFS }\end{array}$ & 14 \\
\hline $\begin{array}{l}\text { No value provided with short-term remuneration } \\
\text { table, but disclosed separately in other sections of } \\
\text { the AFS }\end{array}$ & 35 \\
\hline $\begin{array}{l}\text { Provided in table with short-term remuneration and } \\
\text { separately in other sections of the AFS }\end{array}$ & 51 \\
\hline \multicolumn{2}{|l|}{ Number-based (detail) } \\
\hline Opening balance number of instruments & 78 \\
\hline Number of instruments awarded & 73 \\
\hline Number of instruments exercised & 67 \\
\hline Closing balance number of instruments & 81 \\
\hline \multicolumn{2}{|l|}{ Number-based (overall) } \\
\hline All number-based disclosures provided & 65 \\
\hline Some number-based disclosures provided & 24 \\
\hline No number-based disclosures provided & 11 \\
\hline
\end{tabular}

AFS, annual financial statements; IFRS 2, International Financial Reporting Standard 2.

the disclosures were presented consistently in the same section of the annual report. Results varied from disclosure shown in various sections of the directors' report, to disclosure in different notes to the annual report.

A separate directors' remuneration note to the annual report was most common, followed by utilising the remuneration report (section in the directors' report) (Table 2). It can be concluded that the placement of the per-director share-based remuneration data varied and was inconsistent. King IV addresses this inconsistency, by explaining that the remuneration report (section of the directors' report) should include the implementation of the company's remuneration policy (i.e. the per-director share-based remuneration data) (IoDSA 2016).

\section{Value-based disclosures}

Both the Act and King III require companies to disclose a perdirector value for share-based remuneration. As the Act does not define how and when this value should be measured (Dippenaar 2018), a value that was measured at any date (grant date, reporting date or exercise date) and in any way (at fair value, intrinsic value or as the gain realised on exercise) was assumed to comply with the Act. Only 6\% of the companies sampled (two medium and two small companies) did not disclose any value for their share-based remuneration per director. As $94 \%$ of the companies thus disclosed some form of value for share-based remuneration 
per director, it would seem that almost all companies comply with the Act. King III, on the other hand, requires disclosure of the grant date fair value. This King III requirement was only adhered to by $37 \%$ of the companies (which is a high level of non-compliance) (Table 2). The gain on exercise of share-based remuneration was disclosed most frequently by the selected companies. This might be a remnant of the 1973 Act, which required disclosure of the gain on exercise of share options. Companies might have expanded their existing 1973 Act disclosure to include all types of instruments.

Only $14 \%$ of companies disclosed a per-director value for share-based remuneration together with other short-term remuneration in a table, adding it to the short-term remuneration to calculate comprehensive remuneration per director. A total of $35 \%$ of companies disclosed a value separately from other short-term remuneration. However, the majority of the companies (51\%) employed both versions (Table 2). An annexure to the King III remuneration practice note (containing a remuneration report template) shows disclosure of cash-based long-term incentives in a table with other short-term remuneration elements, as well as a separate table with details pertaining to all long-term incentive awards (IoDSA 2013). This template might explain why the majority of the companies employed both versions (some information in table with short-term remuneration and some information separately). Where a value for share-based remuneration was disclosed with other short-term remuneration (this was the case for $65 \%$ of the companies, as shown in Table 2), data regarding the nature of the value were also collected (Table 3). Table 3 shows the number of instances that a certain value was employed. The total of Table 3 does not equal the total number of companies that disclosed the information with other short-term remuneration (which was 41). The reason for this was that some companies employed more than one value in the table, albeit often in respect of different schemes employed by the company.

The gain on exercise was the value disclosed most often in the table together with other short-term remuneration (this could be seen as a remnant of the 1973 Act's requirement to disclose the gain on exercise of options). The second most popular value was the grant date fair value of instruments awarded during the year (this could be seen as an attempt to comply with King III). Other values included issue price, IFRS liability relating to shares and intrinsic value. Considering that some companies disclosed the value relating to share-based remuneration with short-term remuneration in a table, while others did not, and the variations used to measure the value of share-based

TABLE 3: Measurement of value disclosed in table with short-term remuneration.

\begin{tabular}{lc}
\hline Value disclosed & Number of instances \\
\hline Exercise date fair value (same as gain on exercise) & 20 \\
$\begin{array}{l}\text { Fair value of instruments awarded during year } \\
\text { (grant date fair value) }\end{array}$ & 12 \\
IFRS 2 expense & 7 \\
Other & 5 \\
\hline Total & 44 \\
\hline
\end{tabular}

IFRS 2, International Financial Reporting Standard 2. remuneration, it was concluded that substantial inconsistency exists in the disclosure of the value of directors' share-based remuneration. This inconsistency could also affect the reliability of the values captured by financial databases regarding share-based remuneration, as these are often captured based on the amounts disclosed in the table (with short-term remuneration).

\section{Number-based disclosures: Details on number of instruments}

The JSE listing requirements require per-director disclosure of the number of share-based instruments held at the beginning and the end of the reporting period, as well as the number of instruments awarded and exercised during the period. The number of instruments held as closing balance was disclosed most frequently, with number of instruments exercised during the period showing the lowest disclosure rate (Table 2). A possible reason for the lower disclosure rates for number awarded and exercised could be that not all companies had such activities during the year, but this was difficult to ascertain because of limited and inconsistent disclosure by companies. Most companies complied with all the disclosure requirements relating to the number of instruments, while only $11 \%$ complied with none of the requirements (Table 2 ).

\section{Differences between industries}

A chi-square analysis was performed to determine if there were statistically significant differences regarding the sharebased remuneration disclosure of companies in the financial, industrial and basic materials industries. Table 4 shows the chi-square results regarding the share-based remuneration disclosure in the annual report, when comparing companies in the three industries.

Only one significant difference was noted when comparing companies in different industries. This related to the value disclosed in the table with short-term remuneration. Companies in the basic materials industry were significantly more likely to disclose the gain on exercise in the table than companies in the other two industries (Table 4). As only one statistically significant difference was noted when conducting comparisons between industries, it can be concluded that the industry in which the company operates was not the main determinant of the disclosure quality (compliance and consistency) relating to the per-director disclosure practices of share-based remuneration. In the next section, company size will be evaluated as a determinant of disclosure quality.

\section{Differences between large, medium and small companies}

A chi-square analysis was performed to determine if there were statistically significant differences regarding the sharebased remuneration disclosure of small, medium and large companies (Table 5). 
TABLE 4: Share-based remuneration compared between industries.

\begin{tabular}{|c|c|c|}
\hline Variables & Chi-square & $p$ \\
\hline \multicolumn{3}{|l|}{ Location-based } \\
\hline Directors' report (general section) & 1.15 & 0.56 \\
\hline $\begin{array}{l}\text { Separate section of the directors' report called } \\
\text { 'Remuneration report' }\end{array}$ & 1.46 & 0.48 \\
\hline Directors' remuneration note to AFS & 0.13 & 0.94 \\
\hline Related parties' note to AFS & 0.00 & 1.00 \\
\hline IFRS 2 note to AFS & 3.66 & 0.16 \\
\hline \multicolumn{3}{|l|}{ Value-based (disclosed anywhere in AFS) } \\
\hline Exercise date fair value or gain on exercise & 0.57 & 0.75 \\
\hline Fair value of instruments awarded during year & 0.14 & 0.93 \\
\hline IFRS 2 expense & 1.02 & 0.60 \\
\hline Fair value at reporting date & 5.13 & 0.08 \\
\hline \multicolumn{3}{|l|}{ Value-based (placement of values) } \\
\hline $\begin{array}{l}\text { Provided in table with short-term remuneration, but no } \\
\text { further information in the remainder of AFS }\end{array}$ & 0.00 & 1.00 \\
\hline $\begin{array}{l}\text { No value provided with short-term remuneration table, but } \\
\text { disclosed separately in other sections of the AFS }\end{array}$ & 4.09 & 0.13 \\
\hline $\begin{array}{l}\text { Provided in table with short-term remuneration and } \\
\text { separately in other sections of the AFS }\end{array}$ & 3.61 & 0.16 \\
\hline \multicolumn{3}{|l|}{ Value-based (which value in other short-term remuneration table) } \\
\hline Exercise date fair value or gain on exercise & 13.16 & $<0.01 * * *$ \\
\hline Fair value of instruments awarded during year & 2.56 & 0.28 \\
\hline IFRS 2 expense & 0.31 & 0.86 \\
\hline Other & 0.47 & 0.79 \\
\hline \multicolumn{3}{|l|}{ Number-based } \\
\hline Opening balance of instruments & 0.71 & 0.70 \\
\hline Number of instruments awarded & 0.63 & 0.73 \\
\hline Number of instruments exercised & 1.33 & 0.51 \\
\hline Closing balance of instruments & 0.62 & 0.73 \\
\hline No number of instruments disclosed & 0.31 & 0.86 \\
\hline
\end{tabular}

AFS, annual financial statements; IFRS 2, International Financial Reporting Standard 2.

$* * *$, significant at $1 \%$ level.

Regarding the location of share-based remuneration, no significant differences were noted between small, medium and large companies. However, significant differences were noted in the value-based and number-based disclosures. Regarding values disclosed anywhere in the annual report, large companies were most likely to disclose the grant date fair value of instruments awarded and the gain on exercise (both significant differences, $p<0.01$ ), while small companies were the least likely. Small companies were more likely not to have granted or exercised any instruments in a certain financial year. Small companies were more likely to disclose the IFRS 2 expense somewhere in the annual report than large and medium companies $(p=0.03)$ (Table 5).

Large companies were significantly less likely to only disclose share-based remuneration in the table with other remuneration and not provide further information elsewhere $(p=0.02)$. Medium and small companies were significantly more likely to provide share-based information only in the table (with no further information elsewhere). Large companies were significantly more likely to disclose specifically the grant date fair value of share-based remuneration awarded in the table with other remuneration than were medium and small companies $(p<0.01)$. As such, large companies were more likely to comply with King III's requirement to disclose the grant date fair value. On the other hand, small companies were significantly more likely to disclose the IFRS 2 expense $(p<0.01)$ or other values $(p=0.04)$
TABLE 5: Share-based remuneration compared between company sizes.

\begin{tabular}{|c|c|c|}
\hline Variables & Chi-square & $p$ \\
\hline \multicolumn{3}{|l|}{ Location-based } \\
\hline Directors' report (general section) & 1.15 & 0.56 \\
\hline $\begin{array}{l}\text { Separate section of the directors' report called } \\
\text { 'Remuneration report' }\end{array}$ & 3.51 & 0.17 \\
\hline Directors' remuneration note to AFS & 0.51 & 0.77 \\
\hline Related parties note to AFS & 2.56 & 0.28 \\
\hline IFRS 2 note to AFS & 3.66 & 0.16 \\
\hline \multicolumn{3}{|l|}{ Value-based (disclosed anywhere in AFS) } \\
\hline Exercise date fair value or gain on exercise & 20.01 & $<0.01 * * *$ \\
\hline Fair value of instruments awarded during year & 10.82 & $<0.01 * * *$ \\
\hline IFRS 2 expense & 7.15 & $0.03 * *$ \\
\hline Reporting date fair value & 2.04 & 0.36 \\
\hline \multicolumn{3}{|l|}{ Value-based (placement of values) } \\
\hline $\begin{array}{l}\text { Provided in table with short-term remuneration, but no } \\
\text { further information in the remainder of AFS }\end{array}$ & 8.17 & $0.02 * *$ \\
\hline $\begin{array}{l}\text { No value provided with short-term remuneration table, but } \\
\text { disclosed separately in other sections of the AFS }\end{array}$ & 0.14 & 0.93 \\
\hline $\begin{array}{l}\text { Provided in table with short-term remuneration and } \\
\text { separately in other sections of the AFS }\end{array}$ & 3.22 & 0.20 \\
\hline \multicolumn{3}{|l|}{ Value-based (which value in other short-term remuneration table) } \\
\hline Exercise date fair value or gain on exercise & 5.72 & $0.06 *$ \\
\hline Fair value of instruments awarded during year & 11.42 & $<0.01 * * *$ \\
\hline IFRS 2 expense & 10.78 & $<0.01 * * *$ \\
\hline Other & 6.44 & $0.04 * *$ \\
\hline \multicolumn{3}{|l|}{ Number-based } \\
\hline Opening balance of instruments & 13.71 & $<0.01 * * *$ \\
\hline Number of instruments awarded & 16.88 & $<0.01 * * *$ \\
\hline Number of instruments exercised & 22.07 & $<0.01 * * *$ \\
\hline Closing balance of instruments & 12.99 & $<0.01 * * *$ \\
\hline No number of instruments disclosed & 6.28 & $0.04 * *$ \\
\hline
\end{tabular}

as a value in the table with other remuneration (this never occurred for large companies in the sample, and only rarely for medium companies). To conclude this picture, it is worthwhile mentioning that a trend was noticed ( $p=0.06$, i.e. not statistically significant at a $5 \%$ level) that medium companies were more likely to disclose the gain on exercise in the table (Table 5).

Significant differences were also found relating to the disclosure on the number of instruments. Large companies were significantly less likely to neglect disclosing each of the following: the number of instruments held in opening balance, held in closing balance, awarded and exercised (all at $p<0.01$ ). Small companies were the most likely not to disclose any information regarding the number of instruments, with medium companies in second place and large companies the least unlikely not to disclose any of the required number-based information $(p=0.04)$ (Table 5).

\section{Comparison of findings with previous research}

Previous South African studies (Table 1) all reported substantial inconsistency (possibly because of noncompliance with regulatory requirements) in the per-director disclosure practices relating to share-based remuneration. Both non-compliance and inconsistency was noted in the current study. Non-compliance with regulatory requirements 
withholds valuable information from users of annual reports, and companies are then less transparent. The main reason for the inconsistency was the varying disclosure relating to the value of share-based remuneration (companies measured this value on different dates and using different methods). In line with previous South African studies it was found that the disclosure requirements, especially relating to value, should be clarified by the Act (King IV has clarified what the King Report requires). Inconsistency could hamper the comparability of similar companies and thus provide less useful information for decision-making.

In the present study, company size was found to be the main determinant of the disclosure quality (compliance and consistency) relating to the per-director disclosure practices of share-based remuneration, as opposed to industry. These findings agree with most of the previous research on disclosure quality (which has mostly found larger companies to be more likely to comply and provide voluntary information).

\section{Best practice example (Research Objective 2)}

Research Objective 2 was to develop a best-practice disclosure example (Figures 1 and 2) that encapsulates all the requirements of the JSE listing requirements, the Act and King IV. The relevant disclosures required by the JSE listing requirements and the Act are required to be disclosed in the annual report, which includes the directors' report. The South African Institute of Chartered Accountants (SAICA) recommended that the remuneration data required by Section 30 of the Act be disclosed in the notes to the annual report (SAICA 2015). This was, however, before the effective date of King IV, which recommends that all the per-director share-based remuneration data be presented in the remuneration report (section of the directors' report) as part of the company's remuneration implementation report (IoDSA 2016).

Based on the requirements of King IV, the authors propose that per-director disclosure of share-based remuneration should be provided in three separate tables. Firstly, the grant date fair value of share-based remuneration awarded during the period should be included in a table with all other remuneration elements (as defined by the Act) (Dippenaar 2018). In a second table, disclosure should be provided regarding unvested awards: the number of the awards, the dates that the awards vest and expire, the grant date fair value and the fair value at reporting date (see Figure 1 for best-practice example). In a third table, the cash value (fair value on exercise, akin to gain on exercise) should be disclosed regarding awards that were settled during the reporting period (see Figure 2 for best-practice example). In terms of share options, the exercise dates and exercise prices of differing lots should be disclosed (JSE Limited 2017).

Although it is not prescribed, the authors recommend that the second table should disclose a reconciliation of the number of instruments per director. This reconciliation would include the opening balance, instruments granted during the year, instruments exercised during the year, instruments forfeited during the year as well as the instruments held in closing balance at reporting date (illustrated in Figure 1).

If the company has multiple schemes, it is advised that each share-based incentive scheme have its own second and third table, as described above. It is suggested that any additional information relating to the scheme and the directors be disclosed below this table, including an account of the performance measures used, the relative weighting of each and how the organisation and executive managers, individually, performed against the set targets, as required by King IV (IoDSA 2016).

\begin{tabular}{|c|c|c|c|}
\hline \multirow{2}{*}{ Director } & \multicolumn{3}{|c|}{ Exercised during year $\dagger$} \\
\cline { 2 - 4 } & Number & Date $\$$ & Fair value \\
\hline A & & & \\
\hline B & & & \\
\hline C & & & \\
\hline
\end{tabular}

$\dagger$, For share options, the exercise price also needs to be disclosed in respect of the number of options exercised during the year.

\#. This is not required, but provided in order to reconcile the movement in instruments. FIGURE 2: Best practices disclosure example: Instruments exercised during the year.

\begin{tabular}{|c|c|c|c|c|c|c|c|c|c|}
\hline \multirow{2}{*}{ Director } & \multirow{2}{*}{$\frac{\text { Opening balance } \dagger}{\text { Number }}$} & \multicolumn{3}{|c|}{ Awarded during year } & \multirow{2}{*}{$\frac{\text { Exercised during year } \dagger}{\text { Number }}$} & \multirow{2}{*}{$\frac{\text { Forfeited during year } \dagger}{\text { Number }}$} & \multicolumn{3}{|c|}{ Closing balance $\ddagger \S$} \\
\hline & & Number & Grant date & Fair value & & & Number & Fair value & Vesting dateq \\
\hline A & & & & & & & & & \\
\hline B & & & & & & & & & \\
\hline c & & & & & & & & & \\
\hline
\end{tabular}

$\dagger$, These are not required, but provided in order to reconcile the movement in instruments.

$\$$ For share options, the exercise price also needs to be disclosed for each of these categories

$\S$, When considering the closing balance, the different lots (that vest on different dates) should clearly be distinguished.

I, If the expiry date differs from the vesting date, this should also be disclosed for all instruments.

FIGURE 1: Best practices disclosure example: Instruments not yet vested. 


\section{Conclusion}

The JSE listing requirements, the Act and the King Report require share-based directors' remuneration to be disclosed on a per-director basis. These disclosures mostly focus on the number and value of instruments held, awarded and exercised. In previous studies, non-compliance and inconsistencies in the disclosure practices of locally listed companies were mentioned but not fully documented. The first objective of this study was to examine the disclosure practices of listed companies, to determine whether they complied with regulatory requirements and whether company disclosures were consistent. Non-compliance with regulatory requirements could expose the company to censures or fines by the JSE as well as the suspension or termination of the company's JSE listing. Directors could be held responsible for any losses incurred by the company and possibly removed from office, based on the provisions of the Act.

The per-director disclosures were presented in different places in the annual reports, leading to incomparability. Almost all companies provided some form of disclosure relating to the value of the share-based remuneration, thus complying with the Act (which does not specify when and how the disclosed value should be measured). King III (effective at the time of the study) required the grant date fair value to be disclosed, which was only disclosed by $37 \%$ of companies. Accordingly, a lower level of compliance with King III (than with the Act) was noted.

The values were also disclosed inconsistently. Some companies only disclosed the value in the table with shortterm remuneration and provided no further information. Other companies disclosed the value only separately from the short-term remuneration table. A third group of companies provided information both in the table and separate from the table. Finally, most companies complied with the JSE listing requirements in terms of disclosing the number of instruments held, awarded and exercised.

The aforementioned disclosure was also compared between the financial, industrial and basic materials industries and companies of different sizes. The disclosure practices of companies in different industries only differed in one respect, while many differences in disclosure practices were noted between companies of different sizes. It was therefore concluded that company size is the main determinant of disclosure quality. Large companies were more likely (than small companies) to comply with regulatory requirements. Large companies were more likely to disclose the grant date fair value (and so comply with King III), whereas small companies were more likely to disclose the IFRS 2 expense (in the table with short-term remuneration).

Given the inconsistency noted in the first research objective, a best-practice disclosure example was provided as the second research objective of the study. This example complies with the JSE listing requirements, the Act and King IV and can be applied in future by companies seeking to comply with regulatory requirements applicable to per-director share-based remuneration disclosures. The disclosures should be presented in the remuneration report (section of the directors' report).

\section{Practical implications}

The results of the study contain practical implications for the preparers and users of annual reports, as well as for South African regulators, such as the JSE and the King Committee on Corporate Governance. Firstly, the preparers of annual reports should ensure compliance with all the applicable regulatory requirements pertaining to the per-director disclosure of share-based remuneration. Non-compliance decreases the transparency of annual reports and diminishes their usefulness in providing information for decision-making. To assist preparers, a best-practice disclosure example was developed that complies with the per-director disclosure requirements of the Act, the JSE listing requirements and King IV.

The results of this study are useful for shareholders and other users of annual reports, as they raise awareness of the various regulatory disclosure requirements pertaining to per-director share-based remuneration. The findings highlight the inconsistency of the disclosures provided by listed companies in their annual reports. These inconsistencies make comparisons between companies difficult. Shareholder activism (shareholders who place pressure on companies to provide complete and consistent disclosures in their annual report) could improve disclosure quality in future.

Lastly, this study can assist regulators by helping them to identify areas of non-compliance with regulatory requirements, in general, and inconsistencies between the Act and the King Report more specifically. Currently the Act does not define how and when the value of share-based remuneration to be disclosed should be measured. This uncertainty, which leads to inconsistent disclosure of the value of share-based remuneration, can be addressed by regulators. King IV clarifies exactly which values (grant date fair value, fair value at reporting date as well as gain on exercise) listed companies should disclose in their annual reports to comply with the King Report. However, unlisted companies (that do not need to comply with King IV) might still be unsure how to calculate a value for share-based remuneration to disclose in compliance with the Act. However, it is hoped that the implementation of King IV will remove some of the inconsistencies in disclosures between listed companies.

\section{Limitations of the study and future research opportunities}

The findings of this study cannot be generalised to all the companies listed on the JSE, because only a limited sample of 62 companies was used. Furthermore, only three industries (basic materials, financial and industrial) were studied, and consequently the results cannot be generalised to all the JSE industries. Future research could include extending the study to all the companies listed on the JSE (thereby also covering 
all the JSE industries). The disclosure practices of companies in the period after King IV became effective could be examined (to determine compliance and consistency and/or whether or not there has been an improvement in companies' disclosure practices in light of the more detailed requirements of King IV).

\section{Acknowledgements Competing interests}

The authors declare that they have no financial or personal relationships that may have inappropriately influenced them in writing this article.

\section{Authors' contributions}

G.S. and M.D. acted as project leaders, were responsible for the project design and co-wrote the manuscript. D.F. and C.F. collected data from the annual financial statements, analysed the data and co-wrote the manuscript.

\section{Disclaimer}

The views expressed in this article are the authors' own and not the official position of the institution.

\section{References}

Bebchuk, L.A., Fried, J. \& Walker, D., 2002, 'Managerial power and rent extraction in the design of executive compensation', University of Chicago Law Review 69, 751-846. https://doi.org/10.2307/1600632

Clarkson, P., Van Bueren, A.L. \& Walker, J., 2006, 'Chief executive officer remuneration disclosure quality: Corporate responses to an evolving disclosure environment', Accounting and Finance 46(5), 771-796. https://doi.org/10.1111/j.1467629X.2006.00197.x

Crafford, W.L., 2015, 'The relationship between directors' remuneration and financial performance: An investigation into South African JSE-listed industrial firms', MCom thesis, Department of Business Management, Stellenbosch University.

Conyon, M.J., Mallin, C. \& Sadler, G., 2002, 'The disclosure of directors' share option information in UK companies', Applied Financial Economics 12, 95-103. https:// doi.org/10.1080/09603100110088076

Coulton, J.J., James, C. \& Taylor, S.L., 2001, The effect of compensation design and corporate governance on the transparency of CEO compensation disclosures,
working paper no. 45, UTS School of Accounting, viewed 11 October 2018, from working paper no. 45, UTS School of A
https://doi.org/10.2139/ssrn.273628.

Dippenaar, M., 2018, 'A critical analysis of the meaning of the term "value" in Section 30(6)(e) of the Companies Act', South African Journal of Economic and Management Sciences 21(1), 1-9.

Dippenaar, M. \& Steenkamp, G., 2017, 'Disclosure of directors' remuneration', Accountancy SA November 2017, 54-56. https://doi.org/10.4102/sajems. v21i1.1985

Fischer, S.A., 1989, 'Comparability in financial reporting', The Journal of Business Forecasting Methods and Systems 8(3), 9-11.

International Accounting Standards Board (IASB), 2004, IFRS 2 - Share-based payments, IFRS Foundation, London.

International Accounting Standards Board (IASB), 2010, The conceptual framework for financial reporting chapter 3: Qualitative characteristics of useful financial information, IFRS Foundation, London.

Institute of Directors in Southern Africa (IoDSA), 1994, King report on corporate governance, loDSA, Johannesburg.

Institute of Directors in Southern Africa (IODSA), 2002, King report on corporate governance for South Africa-2002, IoDSA, Johannesburg.

Institute of Directors in Southern Africa (IoDSA), 2009, King report on corporate governance for South Africa 2009, IoDSA, Johannesburg.

Institute of Directors in Southern Africa (IoDSA), 2013, Practice notes - A guide to the application of King III: Remuneration, IoDSA, Johannesburg.

Institute of Directors in Southern Africa (IoDSA), 2016, King IV report on corporate governance for South Africa 2016, IoDSA, Johannesburg.
Jaafar, M.Y., Nawawi, A. \& Salin, A.S.A.P., 2014, 'Directors' remuneration disclosure and firm characteristics - Malaysian evidence', International Journal of Economics and firm characteristics - Malaysian
and Management 8(2), 269-293.

Jensen, M.C. \& Meckling, W.H., 1976, 'Theory of the firm: Managerial behaviour, agency costs and ownership structure', Journal of Financial Economics 3, 305-360. https://doi.org/10.1016/0304-405X(76)90026-X

Johannesburg Stock Exchange (JSE) Limited, 2016, Understanding JSE investigations and the imposition of censures, viewed 04 October 2018, from https://www.jse. co.za/content/JSEEducationltems/CensuresBrochure.pdf.

Johannesburg Stock Exchange (JSE) Limited, 2017, JSE Limited listing requirements, viewed 26 May 2017, from https://www.jse.co.za/content/JSERulesPoliciesand Regulationltems/JSE\%20Listings\%20Requirements.pdf.

Madlela, V. \& Cassim, R., 2017, 'Disclosure of directors' remuneration under South African company law: Is it adequate?', South African Law Journal 134(2), 383-41. https://doi.org/10.1016/j.sbspro.2015.01.417

Malak, S.S.D.A., 2015, 'The determinants of disclosure of individual executive director's remuneration: A Malaysian perspective', Procedia - Social and Behavioral Sciences 172, 666-673. https://doi.org/10.1016/j.sbspro.2015.01.417

Massie, K., Collier, D. \& Crotty, A., 2014, Executive salaries in South Africa: Who should have a say on pay?, Jacana Media, Auckland Park.

Mavrodinov, N., 2012, 'The changing landscape of long-term share-based compensation in South Africa', MCom thesis, Department of Finance \& Tax, University of Cape Town.

Murphy, K.J., 2012, Executive compensation: Where we are, and how we got there, working paper no. FBE 07.12, Marshall School of Business, viewed 09 June 2017 , from https://papers.ssrn.com/sol3/papers.cfm?abstract_id=2041679.

Ntim, C.G., Lindop, S., Osei, K.A. \& Thomas, D.A., 2015, 'Executive compensation, corporate governance and corporate performance: A simultaneous equation approach', Managerial and Decision Economics 36, 67-96. https://doi. org/10.1002/mde.2653

Ntim, C.G., Opong, K.K., Danbolt, J. \& Thomas, D.A., 2012, 'Voluntary corporate governance disclosure by Post-Apartheid South African corporations', Journal of Applied Accounting Research 13(2), 122-144. https://doi.org/10.1108/096754 21211254830

Pretorius, D. \& De Villiers, C., 2013, 'The effect of expensing share-based payments on basic earnings per share of South African listed companies', Meditari Accountancy Research 21(2), 178-190. https://doi.org/10.1108/MEDAR-03-2013-0006

PricewaterhouseCoopers, 2012, Making executive pay work: The psychology of incentives, viewed 03 February 2017, from https://www.pwc.com/gx/en/hrmanagement-services/publications/assets/making-executive-pay-work.pdf.

PricewaterhouseCoopers, 2015, Executive directors: Practices and remuneration trends report, 7th edn., South Africa, viewed 13 July 2018, from https://www. pwc. co.za/en/assets/pdf/executive-directors-report07.2015.pdf.

PricewaterhouseCoopers, 2018, Executive directors: Practices and remuneration trends report, 10th edn., South Africa, viewed 13 July 2018, from https://www. bbrief.co.za/content/uploads/2018/07/Executive-directors-Practices-andremuneration-trends-report-2018.pdf.

Republic of South Africa, 1973, Companies Act 61 of 1973, Government Printer, Pretoria.

Republic of South Africa, 2008, Companies Act 71 of 2008, Government Printer, Pretoria.

Scholtz, H. \& Smit, A., 2015, 'Factors influencing corporate governance disclosures of companies listed on the Alternative Exchange (AltX) in South Africa', South African Journal of Accounting Research 29(1), 29-50. https://doi.org/10.1080/10291954. 2015.999471

South African Institute of Chartered Accountants (SAICA), 2015, Disclosure of directors' and prescribed officers' remuneration - Frequently asked questions, directors and prescribed officers' remuneration - Frequently asked questions,
viewed 13 March 2018, from https://www.saica.co.za/Portals/0/Technical/ vegalAndGovernance/Companies\%20Act/SAICA_FAQ_on_Disclosure_of_ LegalAndGovern

Steenkamp, G. \& Wesson, N., 2018, 'Share-based incentives for South African CEOs: Trends 2002-2015', South African Journal of Accounting Research 32(1), 46-70. https://doi.org/10.1080/10291954.2017.1409869

Steyn, G.F., 2015, 'The relationship between CEO compensation and future share returns in South Africa', MCom thesis, Department of Accounting, University of the Western Cape.

Steyn, F. \& Cairney, C., 2016, 'Long-term incentives: Do shareholders get what they pay for?', Southern African Accounting Association National Teaching and Learning and Regional Conference Proceedings, Cape Town, South Africa, September 2, 2016, pp. 244-267.

Thomson, C., Carpenter, R., Harber, M. \& Graham, M., 2018, 'An examination of the quality of the variable portion of executive directors' remuneration for large South African listed companies', African Journal of Business and Economic Research 13(2), 25-59. https://doi.org/10.31920/1750-4562/2018/v13n2a2

Urson, M., 2016, 'CEO pay ratios and company performance: A study of JSE-listed consumer goods and services companies', MCom thesis, Department of Finance \& Tax, University of Cape Town.

Voller, R., 2016, Notice no. 20 to customers: Non-disclosure of remuneration and benefits of directors and prescribed officers in annual financial statements, viewed 09 June 2017, from http://www.cipc.co.za/files/8414/5796/3772/Notice_20_ of_2016.pdf. 